\title{
Perfil dos Clientes Inadimplentes de uma Empresa de Factoring em uma Capital Brasileira Baseada na Teoria da Curva Abc
}

Factoring: Analysis of the Profile of Independent Customers from a Factoring Company in a Brazilian Capital Based on the ABC Curve Theory

Perfil de Clientes Morosos de una Empresa de Factoring en una Capital Brasileña Basada en la Teoría de la Curva ABC

\author{
Manoel Carlos de Oliveira Junior ${ }^{1}$ \\ manoelcarlosoliveira@ufam.edu.br \\ http://lattes.cnpq.br/0403290330724360 \\ https://orcid.org/0000-003-4630-0810 \\ Anderson Alfaia Maciel ${ }^{1}$ \\ anderson.maciel144@gmail.com \\ http://lattes.cnpq.br/0641185112576092 \\ https://orcid.org/0000-0002-1537-8511
}

Universidade Federal do Amazonas, UFAM, Brasil ${ }^{1}$

Recebido em: 12/09/2019 / Revisão: 20/02/2020 / Aprovado em: 31/08/2020

Editores responsáveis: Prof. Dr. Antônio Giovanni Figliuolo Uchôa e Prof. Dr. Jonas Fernando Petry

Processo de Avaliação: Double Blind Review DOI: $\underline{\text { https://10.47357/ufambr.v2i3.6376 }}$ 
Perfil dos Clientes Inadimplentes de uma Empresa de Factoring em uma Capital Brasileira Baseada na Teoria da Curva Abc

\title{
Resumo
}

O presente artigo focaliza o tema inadimplência, a partir dos clientes de uma factoring localizada em Manaus-AM. O objetivo principal é identificar a relação entre o perfil dos clientes inadimplentes e relacioná-los às características das empresas inadimplentes, medindo o índice de inadimplência e possíveis motivos do inadimplemento em um período de 5 anos (2013 a 2017). O factoring tem como características essenciais a flexibilidade e dinamismo, e sua principal função é fomentar o setor produtivo. Um dos objetivos específicos é verificar a contribuição do factoring nas micro e pequenas empresas, bem como traçar o perfil dos inadimplentes e causas do inadimplemento. A análise baseou-se na teoria da Curva ABC, por meio do agrupamento e priorização dos dados. Os clientes foram segmentados segundo seu percentual de inadimplência. Ao final, obteve-se um painel que contém indicadores da carteira de clientes, para que o gestor subsidie suas decisões sobre o panorama da empresa em determinado momento. Os principais fatores apontados para inadimplência foram: Fator de Compra, Tempo de Fundação e Tempo de Cadastro, condicionantes para o endividamento dos clientes. Constatou-se menor "rigidez" na análise do crédito em função do tempo de cadastro junto à factoring. Assim, faz-se necessário manter a rigidez quanto à análise desses créditos para diminuição do endividamento dos clientes. Verificou-se que empresas de Sociedade Limitada, no segmento de serviços, são mais tendenciosas a não honrar com o pagamento, e consequentemente se tornar inadimplentes.

Palavras-Chave: Factoring. Inadimplência. Risco. Curva ABC

Factoring: Analysis of the Profile of Independent Customers from a Factoring Company in a Brazilian Capital Based on the ABC Curve Theory

\begin{abstract}
This article focuses on the topic of default, from the clients of a factoring located in ManausAM. The main objective is to identify the relationship between the profile of the defaulting clients and to relate them to the characteristics of the defaulting companies by measuring the default rate and possible reasons for default in a period of 5 years (2013 to 2017). Flexibility and dynamism are key factors in factoring, and their main function is to foster the productive sector. One of the specific objectives is to verify the contribution of factoring in micro and small companies, as well as to outline the profile of the defaulters and causes of default. The analysis was based on ABC Curve theory, through the grouping and prioritization of the data. Customers were segmented according to their default percentage. In the end, a panel was obtained that contains indicators of the client portfolio, so that the manager subsidizes his decisions on the panorama of the company at a given moment. The main factors pointed out to default were: Purchase Factor, Foundation Time and Registration Time, conditions for clients' indebtedness. It was observed a lower "rigidity" in the analysis of the credit as a function of the registration time with factoring. Thus, it is necessary to maintain the rigidity regarding the analysis of these credits to reduce the indebtedness of the clients. It has been found that limited liability companies in the services segment are more inclined to default on payment and consequently become defaulters.
\end{abstract}

Keywords: Factoring. Consumer default. Risk. ABC curve 
Perfil dos Clientes Inadimplentes de uma Empresa de Factoring em uma Capital Brasileira Baseada na Teoria da Curva Abc

\section{Perfil de Clientes Morosos de una Empresa de Factoring en una Capital Brasileña Basada en la Teoría de la Curva ABC}

\section{Resumen}

Este artículo se centra en el tema de incumplimiento, de los clientes de una factorización ubicada en Manaus-AM. El objetivo principal es identificar la relación entre el perfil de los clientes en incumplimiento y relacionarlos con las características de las compañías en incumplimiento mediante la medición de la tasa de incumplimiento y las posibles razones de incumplimiento en un período de 5 años (2013 a 2017). La flexibilidad y el dinamismo son factores clave en el factoraje, y su función principal es fomentar el sector productivo. Uno de los objetivos específicos es verificar la contribución de la factorización en micro y pequeñas empresas, así como describir el perfil de los morosos y las causas del incumplimiento. El análisis se basó en la teoría de la curva $\mathrm{ABC}$, a través de la agrupación y la priorización de los datos. Los clientes fueron segmentados de acuerdo a su porcentaje predeterminado. Al final, se obtuvo un panel que contiene indicadores de la cartera de clientes, de modo que el gerente subsidia sus decisiones sobre el panorama de la compañía en un momento dado. Los principales factores señalados como incumplimiento fueron: Factor de compra, Tiempo de fundación y Tiempo de registro, condiciones para el endeudamiento de los clientes. Se observó una menor "rigidez" en el análisis del crédito en función del tiempo de registro con factoring. Por lo tanto, es necesario mantener la rigidez en el análisis de estos créditos para reducir el endeudamiento de los clientes. Se ha encontrado que las compañías de responsabilidad limitada en el segmento de servicios están más inclinadas a incumplir el pago y, por lo tanto, a convertirse en morosos.

Palabras clave: Factoring. Inadimplência. Riesgo. Curva ABC 
Perfil dos Clientes Inadimplentes de uma Empresa de Factoring em uma Capital Brasileira Baseada na Teoria da Curva Abc

\section{INTRODUÇÃOO}

Com frequência empresas utilizando recursos próprios não conseguem manter-se de forma competitiva no mercado ou até mesmo fazer a liquidação em dia de seus débitos perante funcionários, fornecedores e o governo. De acordo com os dados divulgados em uma pesquisa realizada pelo Serviço de Apoio às Micro e Pequenas Empresas (SEBRAE, 2014) já no primeiro ano de atividades de uma empresa, a falta de capital (caixa) é tida como a segunda dificuldade mais significativa para continuidade do negócio, perdendo apenas para a dificuldade de formação de clientes.

A tarefa de gerir o caixa de uma empresa não é simples e envolve uma série de questões que podem ser gerenciadas ou não pelos responsáveis do negócio (ex. prazo de pagamentos de fornecedores e recebimento de clientes; pagamentos de funcionários e seus benefícios; roubos e fraudes). Embora seja uma tarefa desafiadora, a gestão do caixa de uma empresa pode ser auxiliada por bancos ou empresas financeiras que, se necessário, podem fornecer recursos para as organizações empresariais saldarem obrigações de curto prazo.

Segundo a norma internacional de contabilidade para ativos financeiros (IASB, 2014 - IFRS9), existem duas modalidades principais de antecipação de recebíveis: (1) a que transfere substancialmente o risco do instrumento financeiro para quem adquire o título e (2) outra em que a companhia detentora fica com os riscos de não pagamento do título, utilizando o instrumento financeiro como uma mera garantia para captação de recursos junto ao banco.

A primeira forma de antecipação de recebíveis é conhecida pelo mercado como venda de recebíveis (securitização). Nela ocorre a efetiva venda do título e sua respectiva baixa contábil pelo vendedor.

A segunda forma de antecipação, por sua vez, é conhecida como desconto de cheques ou duplicatas (ou das vendas parceladas pelo cartão de crédito) e é a modalidade mais comum, principalmente no âmbito das companhias de pequeno porte. Nesta situação ocorre apenas a transferência de fundos do banco (ou operadora financeira) para a empresa que cede em garantia às duplicatas ou os cheques que têm a receber. A grande vantagem desta modalidade em relação ao empréstimo de giro são as taxas cobradas, substancialmente menores do que em empréstimos sem garantia.

Para captar recursos com antecipação de duplicatas ou cheques, uma organização pode recorrer a um banco comercial ou a uma empresa de fomento (factorings). Nas factorings o custo da antecipação é medido pelo fator de compra. Este fator representa a taxa efetiva cobrada pelas empresas de fomento, juntamente com sua margem e custos diretos e indiretos totais (Capelletto \& Corrar, 2008; Wolf, 2008; Leite, 2011; Gonçalves, Gouvêa \& Mantovani, 2013; Anfac, 2017).

As soluções de crédito oferecidas pela empresa de factoring estudada são: compra de duplicatas; cheques pré-datados; adiantamento para compra de matéria prima e mercadorias. Após o vencimento e não pagamento do título negociado (inadimplência), a empresa de factoring negociará diretamente com a empresa devedora ou renegociado com a empresa cliente. Na primeira situação a factoring faz a cobrança a empresa que deveria ter efetuado a liquidação, sem o envolvimento da empresa que vendeu o título. Na segunda situação, é decidido que a empresa que vendeu o recebível irá fazer a quitação por meio de uma recompra 
Perfil dos Clientes Inadimplentes de uma Empresa de Factoring em uma Capital Brasileira Baseada na Teoria da Curva Abc

em uma de suas operações de negociação, e o pagamento com a empresa devedora é acertado entre as partes que deram origem ao título. A cobrança sobre a empresa que vendeu o recurso é chamada de direito de regresso, sendo defendida por alguns autores e não aceita por outros.

No Brasil, Luiz Lemos Leite é o precursor do factoring, por esta razão o presente trabalho considera o que foi escrito por ele, não aprofundando sobre o direito de regresso. Leite (2011, p.225), evidencia que "o cedente transfere seu crédito ao cessionário, deixando de ser credor; o cessionário assume o papel de credor, tomando o lugar do cedente na relação jurídica". Porém, a empresa cliente pode assumir o valor devido ao título. Para Leite (2011), "a empresa-cliente vendedora não é devedora, não sendo obrigada a restituir o valor recebido pela falta de pagamento, mas apenas porque, por força do endosso, assumiu a garantia de solvência do sacado, que é o verdadeiro devedor da operação" (p. 225).

Considerando estas premissas, os objetivos específicos deste artigo são: identificar o perfil dos clientes inadimplentes e os possíveis motivos que condicionaram a empresa nesse cenário, analisando e comparando os dados coletados.

\section{REFERENCIAL TEÓRICO}

Esta seção trata dos principais conceitos relativos ao tema do artigo, com foco em uma visão geral do factoring, suas modalidades e elementos que perpassam as atividades desse tipo de fomento.

\subsection{Visão Geral do Factoring}

Denomina-se factoring, a atividade de fomento empresarial relacionadas ao apoio às iniciativas empresariais dos clientes, pessoas jurídicas ou profissionais liberais, devidamente registrados em seus conselhos, mediante a antecipação (compra) do recebimento do seu faturamento a prazo, por meio de cheques pré-datados ou duplicatas, o que o torna à vista, e de muitas outras formas de alavancagem dos negócios, como melhorias de fluxo de caixa. A empresa que toma o serviço de uma empresa de fomento empresarial, transforma suas vendas a prazo em vendas à vista, obtendo capital em caixa para realizar suas operações.

O factoring desenvolveu-se principalmente no setor produtivo. De acordo com Corrêa (2004, p.21), "nos Estados Unidos, até as primeiras três décadas do século XX, o factoring estava direcionado às manufaturas de algodão, lã e indústria têxtil". O mesmo autor relata que a atividade se expandiu para outras indústrias (móveis, sapatos, plásticos, produtos químicos, couro, desenhos, brinquedos e eletrodomésticos) graças à crise monetária de $1931 \mathrm{e}$ depois à bancária de 1933, quando assegurou os recursos que os bancos estavam impossibilitados de suprir. (ALVES; SILVA; SIQUEIRA, 2008, p.15)

O fomento mercantil nasceu para melhorar o comércio que praticado nos antigos tempos, devido a isenções tecnológicas e bancárias, por meio de trocas de mercadorias - o escambo, pois não existia moeda.

A palavra factoring para Donini (2004,p.7) "é um termo inglês de origem francesa, que remonta ao latim face. Factor é aquele que faz. A utilização de termos anglo-saxônicos no domínio bancário e econômico é bastante frequente".

Ainda segundo Donini (2004), a operação de factoring ou fomento empresarial no Brasil, resume-se em atos que envolvem compra de crédito, antecipação de recursos não-financeiros 
Perfil dos Clientes Inadimplentes de uma Empresa de Factoring em uma Capital Brasileira Baseada na Teoria da Curva Abc

(matéria-prima) e prestação de serviços convencionais ou diferenciados, conjugados ou separadamente, a título oneroso entre dois empresários, faturizador e faturizado. A faturização consiste na venda da carteira ou parte dela, derivada de faturamento a prazo. Essa venda é efetuada com a condição de o comprador arcar com gastos necessários à cobrança, bem como com todo o risco por eventuais inadimplências dos clientes.

A factoring é uma prestadora de serviços que realiza operações mercantis, e que tem por objetivo a melhoria da qualidade dos procedimentos dos clientes assistidos, em seus diversos níveis de atuação, e que poderá resultar na compra de ativos representados por legítimos efeitos mercantis, oriundos das transações comerciais ou de prestação de serviços a prazo.

A modalidade convencional é a mais praticada no País e considerada a mais típica, que envolve e tem por objeto as seguintes funções desempenhadas: I. Compra de crédito; II. Prestação de serviços convencionais. A modalidade convencional é integrante da remuneração a sociedade de factoring no contexto da compra de crédito.

A palavra maturity traduzida do inglês para o português, tem o melhor significado aplicado de 'no vencimento'. Esta modalidade diferencia-se da convencional, pois, os títulos são remetidos pelo cedente à sociedade de fomento mercantil, por meio da cessão de créditos, que por sua vez, faz a liquidação destes títulos, oriundos das operações mercantis do cedente no vencimento. $\mathrm{O}$ resultado dessa modalidade para o faturizado, traz consigo os seguintes benefícios e vantagens, tais como: I. não vai despender o faturizado com os custos com a cobrança do título; e II. não terá, principalmente, de se preocupar com o inadimplemento do devedor, pois, nesse caso, entendemos que o faturizador deverá assumir o risco pela insolvência, sob pena de não ter o faturizado (cliente da factoring) nenhum atrativo para efetuar a operação (DONINI, 2004).

Para Fortuna (2001, p. 412) "o maturity implica a total assunção de qualquer crédito da empresa pela casa de factoring, ou seja, em caso de calote do devedor, a empresa que contratou os serviços do factoring não sofrerá qualquer prejuízo." Esta modalidade normalmente é conjugada com a convencional, para fins de remuneração a sociedade de factoring.

Na modalidade trustee o faturizado confia à empresa de factoring a gestão de suas contas, que logo passa a administrá-las. No trustee, o objeto do contrato é a prestação de serviços diferenciados, atividade desempenhada pela sociedade de fomento mercantil, envolvendo a gestão de contas a pagar e a receber da empresa faturizada, consultoria e ou parceria. Não ocorre, portanto, a compra do crédito.

A faturizada, na modalidade matéria-prima, não obterá fomento de recursos financeiros, mas, de matéria-prima/insumo e estoque para sua produção (Manufaturação ou industrialização), cujo custo será arcado pelo faturizador (sociedade de fomento mercantil), junto ao fornecedor que terá, em contrapartida, direitos de exclusividade sobre a venda dos produtos oriundos dessa matéria-prima.

Esta modalidade de operação é classificada como antecipação de recursos não-financeiros (de matéria-prima). A remuneração será pactuada entre faturizador e faturizado, tendo como base a venda final dos produtos, cujos insumos e matéria prima foram antecipados pelo faturizador na data base da operação. 
Perfil dos Clientes Inadimplentes de uma Empresa de Factoring em uma Capital Brasileira Baseada na Teoria da Curva Abc

Observa Leite, (1999 p.29) “a vocação histórica do factoring é o mercado internacional. Servirá para comercializar no exterior bens produzidos pelo segmento de nossas pequenas e médias empresas, que não tem a menor possibilidade de fazê-lo". Neste sentido, a modalidade importação-exportação é voltada exclusivamente para o mercado de comércio exterior. E há três frentes de atuação: importação, exportação e a chamada garantia ou securitização.

Sobre a cobrança, Donini, (2004 p.19) evidencia que "o export-factor, ao invés de cobrar diretamente os créditos sobre devedores estabelecidos fora do seu país, contrata uma sociedade de factoring do país devedor (impor-factor) a cobrança desses créditos". Ao contratar uma factoring, a empresa contratante não pagará juros na operação, por não se tratar de empréstimo, mas o chamado deságio que normalmente é baseado na qualidade do sacado-devedor.

O banco pode operar com pessoas físicas e jurídicas. Na PJ ele desconta o recebível cobrando uma taxa de juros (spread) apenas, sem prestar maiores suportes à empresa contratante. E no vencimento do recebível, caso haja inadimplência por parte do sacado-devedor, ele volta-se contra a empresa contratante, cobrando o valor de face dos títulos inadimplidos, somando-se multa e juros do período.

Segundo Donini (2004, p.272), "O spread é formado, normalmente, por três componentes: o risco, o custo administrativo e o lucro do banco. O Banco Central mostrou, em estudo de outubro de 1999, que o spread se compõe assim: custo administrativo $22 \%$, impostos $25 \%$, lucro $18 \%$ e a inadimplência $35 \%$ ".

Junto à sociedade de factoring que obrigatoriamente opera com pessoas jurídicas, a empresa contratante contará com apoio administrativo, acompanhamento e gerenciamento das contas a receber e, em caso de inadimplência do sacado-devedor, serão incorridas as despesas sem prejuízo para a empresa contratante. Em linhas gerais as diferenças são:

Quadro 1: Banco e Factoring atividades que se completam

\begin{tabular}{|l|l|}
\hline \multicolumn{1}{|c|}{ Banco } & \multicolumn{1}{|c|}{ Factoring } \\
\hline $\begin{array}{l}\text { Capta dinheiro e empresta dinheiro. Faz intermediação } \\
\text { de recursos de terceiros, da poupança popular. }\end{array}$ & $\begin{array}{l}\text { Não capta recursos. Presta serviços e compra créditos. } \\
\text { Opera com recursos próprios, não captados do } \\
\text { público. Não coloca em risco a poupança popular. }\end{array}$ \\
\hline $\begin{array}{l}\text { Empresta dinheiro, que é antecipado ou adiantado. } \\
\text { Opera com base no padrão creditício do seu cliente - } \\
\text { pessoa física ou jurídica. }\end{array}$ & $\begin{array}{l}\text { Coloca à disposição do cliente uma gama de serviços } \\
\text { cósica diferenciados. Baseia-se no padrão creditício do } \\
\text { sacado. }\end{array}$ \\
\hline $\begin{array}{l}\text { Cobra juros (remuneração pelo uso do dinheiro } \\
\text { durante determinado prazo). }\end{array}$ & $\begin{array}{l}\text { Mediante preço certo e ajustado com a empresa- } \\
\text { cliente (fator), determinado prazo. Compra a vista } \\
\text { créditos gerados pelas vendas. }\end{array}$ \\
\hline $\begin{array}{l}\text { Instituição Financeira autorizada a funcionar pelo BC } \\
\text { (Lei no 4.595). }\end{array}$ & $\begin{array}{l}\text { Não é instituição financeira. Atividade comercial } \\
\text { mista atípica, (Lei no 4.595). Regida pelo instituto do } \\
\text { direito mercantil. Só opera com pessoa jurídica. }\end{array}$ \\
\hline $\begin{array}{l}\text { Desconta títulos e faz financiamentos. Rege-se pelo } \\
\text { direito financeiro - Bancário. }\end{array}$ & $\begin{array}{l}\text { Não desconta. Compra títulos de créditos ou direitos } \\
\text { creditórios. Direito financeiro - bancário. É cliente do } \\
\text { banco. }\end{array}$ \\
\hline Cliente é seu devedor. & Sacado é seu devedor. \\
\hline IOF - Federal. & $\begin{array}{l}\text { ISS - Municipal - Sobre a comissão cobrada pela } \\
\text { prestação de serviços. }\end{array}$ \\
\hline
\end{tabular}

Fonte: Leite, (1999)

UFAMBR, Manaus, v. 2, n. 3, art. 3, pp. 35-57, julho-dezembro, 2020 http://www.periodicos.ufam.edu.br/ufambr 
Perfil dos Clientes Inadimplentes de uma Empresa de Factoring em uma Capital Brasileira Baseada na Teoria da Curva Abc

\subsection{Análise de crédito factoring}

A análise de crédito em uma empresa de factoring deve abranger não somente as operações de seu cliente, o cedente, mas também, e principalmente, os sacados deste. Isso se dá em função do fato de que o papel da empresa de factoring é analisar a concessão de crédito de seus clientes, tendo como alvo os sacados.

A análise de crédito deve ser executada avaliando-se a compatibilidade entre os fluxos de receitas da empresa analisada e os planos de amortização da dívida proposto, sem deixar de verificar a idoneidade dos clientes. Isso visa garantir o recebimento da dívida e reduzir o risco de moratória destas dívidas.

Entretanto, na venda de um crédito, está implícita a absorção de todos os benefícios ou malefícios que esta transação envolve. A qualquer momento, acontecimentos imprevistos e adversos, como os decorrentes de recessão econômica, podem afetar as fontes primarias de pagamentos de empresas e de pessoas físicas, reduzindo a possibilidade de recebimento do crédito.

\subsection{C's do Crédito}

Segundo Blatt (1999, p. 42), "os c's de crédito fornecem uma visão da complexidade que uma avaliação de crédito pode assumir." Segundo o mesmo autor, essa avaliação se torna essencial para a liberação de uma linha de crédito, tanto na precificação do empréstimo quanto na classificação de risco.

Antes que seja feita qualquer concessão de crédito, o credor tem que ter a certeza de que seu cliente tenha vontade para honrar com suas obrigações, e que investigações mais profundas só são necessárias depois dessa primeira análise (SCHRICKEL, 1995).

Santos (2000, p. 44) afirma: "o objetivo do processo de análise de crédito é o de averiguar a compatibilidade do crédito solicitado com a capacidade financeira do cliente". Por definição, o processo de análise subjetivo envolve decisões individuais quanto à concessão ou recusa de crédito. Nesse processo, a decisão baseia-se na experiência adquirida, disponibilidade de informações e sensibilidade de cada analista quanto ao risco do negócio.

Figura 1 - C's do crédito 
Perfil dos Clientes Inadimplentes de uma Empresa de Factoring em uma Capital Brasileira Baseada na Teoria da Curva Abc

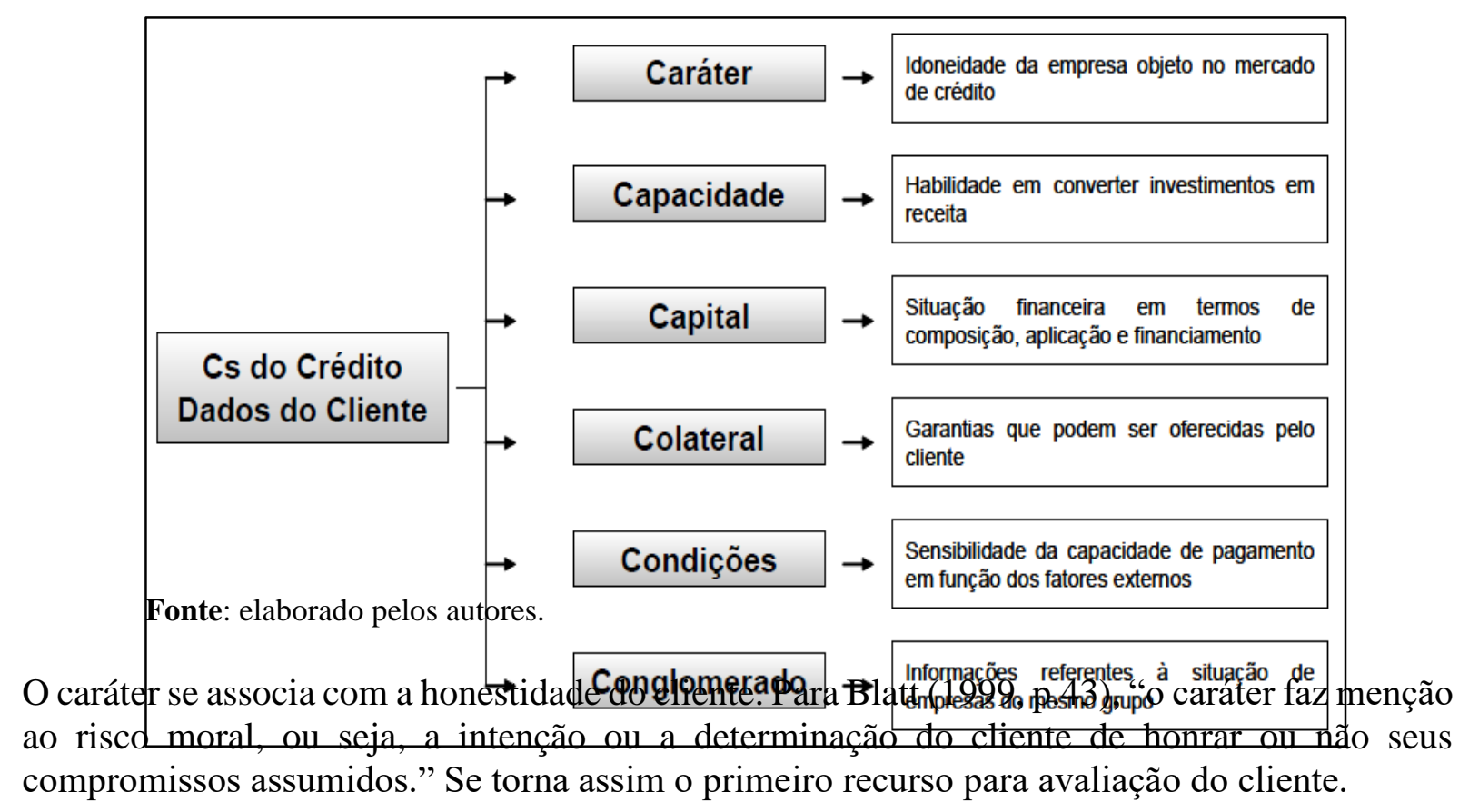

Conforme Schrickel (1995, p. 48), "este é o mais importante e crítico ' $C$ ' em qualquer concessão de crédito, não importando, em absoluto, o valor da transação". O tempo de relacionamento com o banco torna a análise do comportamento financeiro do cliente mais confiável. Por esse motivo, o caráter se torna determinante para a liberação do crédito (SCHRICKEL, 1995). Independente do histórico de bom pagamento do cliente, o seu posicionamento em uma situação de não pagamento, é o que determina seu caráter.

Esse tipo de informação abrange as informações que refletem a idoneidade do cliente. Para a análise desse critério é indispensável aos credores que disponham de informações históricas de seus clientes, sejam elas de fontes internas ou externas, que evidenciem a intencionalidade e pontualidade na amortização de suas dívidas.

A capacidade refere-se ao julgamento subjetivo do analista quanto à habilidade dos clientes no gerenciamento e conversão de seus negócios em receitas. Para empresas, de maneira geral, analisam-se as fontes de receita da empresa enquanto para as pessoas físicas analisa-se a sua renda. O objetivo de se analisar este tipo de informação é determinar se a empresa ou pessoa física tem a capacidade de gerar receitas compatíveis com a amortização da dívida.

O capital é medido pela situação financeira do cliente, levando-se em conta a composição (qualitativa e quantitativa) dos recursos, onde são aplicados e como são financiados. As fontes usuais de informação para a avaliação do capital são os Demonstrativos Contábeis e a Declaração de Imposto de Renda. As pequenas e médias empresas geralmente não utilizam os recursos de auditoria dos seus números contábeis principalmente em função da falta de obrigatoriedade. Empresas com ações negociadas em bolsa ou participantes do mercado financeiro são obrigadas a ter seus balanços e demonstrativos de resultados auditados, o que reduz a chance de haver números mascarados.

A declaração de Imposto de Renda se apresenta como uma boa alternativa de comprovação de renda em vista de que a Receita Federal tem realizado significativos investimentos para 
Perfil dos Clientes Inadimplentes de uma Empresa de Factoring em uma Capital Brasileira Baseada na Teoria da Curva Abc

qualificar os seus procedimentos de análise da declaração de imposto de renda de pessoas físicas e jurídicas. Desta forma, pode-se considerar que este tipo de informação se aproxima da real situação financeira do cliente.

A característica colateral está associada com a análise patrimonial dos indivíduos, considerando uma análise futura para vinculação de bens ao contrato de créditos, em caso de perda da fonte primária de pagamento (SANTOS 2000). Blatt (1999, p. 45) simplifica: "trata-se do oferecimento, por parte do devedor, de garantias que confiram maior segurança ao crédito." e diz ainda que a pergunta chave é: "há uma boa segunda fonte de pagamento para o caso da primeira falhar?"

Afirma Schrickel (1995, p. 54) que o momento do empréstimo deve ser avaliado levando em consideração o micro e macro cenário no qual o tomador de empréstimos está inserido. Para Blatt (1999, p. 46), "as condições fazem menção aos aspectos gerais e conjunturais dos negócios, ramo de atividade e até mesmo do emprego do cliente", ou ainda, a pergunta chave para condições é: a economia, o ramo de atividade do cliente, tem perspectiva favorável para o período do crédito?

Quanto ao conglomerado são as informações relevantes à avaliação de crédito referente a outras empresas do mesmo grupo. Levam em consideração como as empresas coligadas podem afetar a capacidade de pagamento das dívidas das empresas objeto. Com isso, uma empresa que, a princípio, não pareça atrativa, poderia ter melhores condições de crédito uma vez que fossem consideradas as condições do grupo.

Por outro lado, uma organização pode apresentar boas condições de pagamento das dívidas, entretanto, pode tratar-se de uma empresa "fachada" de um grupo em precária situação financeira.

\section{RISCOS}

Para Blatt (1999, p 53), risco é "a probabilidade de que algo por nós esperado e desejado não aconteça, ou que algo indesejado aconteça" consequentemente o risco de crédito, segundo o mesmo autor, é a possibilidade do não pagamento do devedor, nas condições combinadas com aquele que concedeu o crédito. Assim, existem diversos créditos que se tornam impagáveis devido à má avaliação de risco da análise de crédito. Essa análise possibilita evitar o aumento do número de inadimplência por parte dos devedores.

Em todas as operações de crédito, está presente o fator risco pelo simples "fato de que esta concessão patrimonial envolve expectativas quanto ao recebimento de volta da parte cedida. É imperativo reconhecer que a qualquer crédito está associado com a noção de risco." (SCHRICKEL, 1995, p.25)

Além de todas as precauções necessárias na concessão do crédito, é importante o acompanhamento do negócio, algumas alterações e acontecimentos com os clientes podem ocorrer durante o tempo, como desemprego, descontrole financeiro, problemas familiares, dentre outros.

De acordo com Blatt (1999, p.59), “o objetivo básico da análise de crédito consiste em ponderar receita, lucro, fluxo de caixa e riscos de crédito.” A gestão eficaz do risco é condição necessária 
Perfil dos Clientes Inadimplentes de uma Empresa de Factoring em uma Capital Brasileira Baseada na Teoria da Curva Abc

para gerar valor de forma sustentável no tempo. Por sua vez, o risco é assumido em contrapartida de um ganho econômico. De sua gestão eficiente, obtém-se a otimização do capital, maximizando a rentabilidade para um determinado apetite de risco.

Os benefícios com retorno de financeiro concedidos através de créditos têm que ser pesados em relação ao risco creditício. Esse risco inclui a demora no pagamento ou até mesmo o não pagamento da prestação, falência, desemprego, risco de insolvência, entre outros.

\section{INADIMPLÊNCIA}

Para Sandroni (1999, p. 293), a inadimplência é "a falta de cumprimento das cláusulas contratuais em determinado prazo". A não quitação de uma operação no prazo combinado caracteriza o cliente como inadimplente, podendo a Factoring em questão efetuar a cobrança dessa dívida por meios amigáveis e/ou judiciais. A cobrança será executada de forma justa e condizente com os direitos do consumidor.

A não observância das determinações do Código de Defesa do Consumidor é prejudicial à instituição financeira podendo acarretar penalidades previstas na lei.

\section{CURVA ABC}

A curva $\mathrm{ABC}$ (ou curva 80-20), é um método de classificação de informações em que se separam os itens de maior importância, os quais são normalmente em menor número (Carvalho, 2002). Baseada no princípio de Pareto é feita a classificação estatística de materiais, baseada nas quantidades utilizadas e no seu valor. Essa metodologia também pode ser utilizada para classificar clientes em relação aos volumes negociados ou em relação à lucratividade proporcionada, classificação de produtos da empresa pela lucratividade proporcionada, dentre outros aspectos (SACOMANO, 2004).

A curva $\mathrm{ABC}$ é utilizada para a administração de estoques, definição de políticas de vendas, estabelecimento de prioridades, programação de produção, dentre outros (Pinto, 2002). Tem em seus fundamentos o princípio de Pareto, teoria segundo a qual o padrão de distribuição de renda é histórica e geograficamente constante, independentemente das políticas tributárias e de bem-estar social (GOODMAN, 1993).

A análise baseada nas curvas $\mathrm{ABC}$ também permite verificar de imediato os itens críticos do orçamento (insumos ou os serviços que possuem maior representatividade). A partir daí é possível examinar detalhadamente preços, condições de pagamento, alternativas, composições, índices de produtividade, encargos incidentes e tomar as decisões cabíveis (SAMPAIO, 2005).

Para o estudo em questão, a Teoria da Curva ABC serviu como parâmetro analítico com o intuito de identificar $20 \%$ dos clientes inadimplentes da Factoring estudada que detém entre $70 \%$ e $80 \%$ do valor geral de sua inadimplência.

\section{CARACTERIZAÇÃO DA EMPRESA ESTUDADA}

A empresa estudada é uma empresa de fomento mercantil que atua no mercado de Manaus comprando títulos de crédito títulos/recebíveis (duplicatas e cheques pré-datados), provenientes de vendas mercantis ou prestação de serviços. Além de oferecer o serviço de adiantamento para 
Perfil dos Clientes Inadimplentes de uma Empresa de Factoring em uma Capital Brasileira Baseada na Teoria da Curva Abc

compra de matéria prima. Desde a sua fundação, a empresa já comprou mais de 80 mil títulos. Possui estrutura operacional das mais completas em toda região norte/nordeste, o que a torna uma empresa ágil e de grande capacidade para realizar a compra de títulos.

A empresa estudada tem como missão: "Ser uma empresa de fomento mercantil diferenciada no mercado, oferecendo soluções financeiras e administrativas eficientes e atendimento personalizado, proporcionar oportunidades de crescimento para nossos colaboradores e parceiros, contribuindo cada vez mais com o desenvolvimento socioeconômico de nosso país". A definição de visão da empresa estudada é: "Continuar a crescer com responsabilidade e credibilidade junto a nossos clientes, colaboradores e parceiros".

Quanto à cultura e valores da empresa, Robbins (2009, p. 226) afirma que "[...] cultura organizacional se refere a um sistema de valores compartilhados pelos membros de uma organização e que a distingue de outra". A forma de se relacionar e os hábitos dos colaboradores, aliados aos valores, crenças, rituais e normas trabalhadas pela organização, forma a sua cultura. É por meio deste conjunto de características que as organizações buscam atingir seus objetivos.

Assim, a empresa estudada é direcionada pelos seguintes valores: Excelência no atendimento ao cliente; Foco em resultado; Gente que cresce por mérito; Conhecimento compartilhado é conhecimento ampliado; Resiliência para alcançar nossa Missão; Simplicidade e Agilidade; Disciplina em nosso dia-a-dia;

\section{METODOLOGIA}

Quanto aos aspectos metodológicos e meios de investigação o estudo é exploratório e bibliográfico, segundo a classificação feita por Vergara (2003). Exploratório porque há pouco conhecimento acumulado e sistematizado sobre o perfil dos clientes inadimplentes de Factoring.

Quanto aos procedimentos técnicos, este trabalho é considerado um estudo de caso. Para Gil (2002), o estudo de caso é uma modalidade de pesquisa, refere-se no estudo de determinado objeto ou mais que um, de modo que permita seu completo e detalhado conhecimento. Yin (2001), ressalva que apesar de o Estudo de Caso parecer, para muitos, uma pesquisa fácil, ela é extremamente complicada, daí a necessidade da identificação das condições da investigação e do preparo do pesquisador. O estudo de caso é uma situação única em que se lida com inúmeras variáveis de interesse e não apenas com pontos de dados, por isso deve seguir um conjunto de procedimentos pré-especificados.

A pesquisa bibliográfica é justificada pela importância do embasamento teórico do assunto tratado, bem como pela necessidade de se estar atualizado quanto aos recentes artigos científicos, dissertações, jurisprudência e normatização da atividade; além da consulta aos sítios especializados e pela busca de informações em periódicos que abordem o direito do fomento mercantil e gestão do negócio.

Quanto à pesquisa exploratória realizada, foram cedidos pela empresa de Factoring estudada dados referentes às operações financeiras realizadas nos últimos 5 anos, período correspondente de 01/01/2013 a 31/12/2017. Os clientes inadimplentes foram classificados por: (1) 
Perfil dos Clientes Inadimplentes de uma Empresa de Factoring em uma Capital Brasileira Baseada na Teoria da Curva Abc

Enquadramento Jurídico, (2) Segmentos, (3) Data de Fundação (até 6 meses, 1 a 3 anos e + de 3 anos), (4) Data do Cadastro na Factoring (até 6 meses, 1 a 3 anos e + de 3 anos).

Foi usada ainda a ferramenta administrativa da Teoria de Pareto, Curva ABC, para identificar os clientes Classe A, ou seja, os $20 \%$ dos clientes endividados que detém entre $70 \%$ a $80 \%$ de representatividade do valor geral devido.

Foram analisados e relacionados cada um desses clientes Classe A, visando traçar um perfil dos clientes inadimplentes quanto ao seu enquadramento jurídico, segmento, tempo de empresa e tempo de cadastro junto a empresa de Factoring e os possíveis motivos do inadimplemento desses clientes

\section{RESULTADOS}

Como observado foram analisados os dados a partir da coleta de dados de uma base de informações cedidas pela empresa de Factoring estudada. Para as variáveis, os valores foram obtidos em uma base geral de 176 clientes com certo grau de inadimplência.

Quadro 2: Perfil dos Clientes analisados

\begin{tabular}{|c|c|c|c|c|}
\hline Qtd. & \% Vencido & Natureza Jurídica & Porte da Empresa & Segmento \\
\hline 1 & $8,12 \%$ & Sociedade Limitada & Empresa de Pequeno Porte & Serviços \\
\hline 2 & $4,23 \%$ & Sociedade Limitada & Empresa de Pequeno Porte & Serviços \\
\hline 3 & $3,66 \%$ & Empresa Individual & Micro Empresa & Serviços \\
\hline 4 & $3,48 \%$ & Sociedade Limitada & Micro Empresa & Serviços \\
\hline 5 & $3,04 \%$ & Sociedade Limitada & Micro Empresa & Comércio \\
\hline 6 & $3,02 \%$ & Sociedade Limitada & Empresa de Pequeno Porte & Comércio \\
\hline 7 & $2,93 \%$ & Sociedade Limitada & Empresa de Pequeno Porte & Comércio \\
\hline 8 & $2,66 \%$ & Sociedade Limitada & Micro Empresa & Serviços \\
\hline 9 & $2,48 \%$ & Profissional Liberal & Não se aplica & Serviços \\
\hline 10 & $2,46 \%$ & Empresa Individual & Micro Empresa & Serviços \\
\hline 11 & $2,42 \%$ & Sociedade Limitada & Micro Empresa & Serviços \\
\hline 12 & $2,06 \%$ & Empresa Individual & Micro Empresa & Comércio \\
\hline 13 & $1,94 \%$ & Sociedade Limitada & Empresa de Pequeno Porte & Serviços \\
\hline 14 & $1,92 \%$ & Sociedade Limitada & Empresa de Pequeno Porte & Serviços \\
\hline 15 & $1,80 \%$ & Sociedade Limitada & Micro Empresa & Serviços \\
\hline 16 & $1,75 \%$ & Sociedade Limitada & Micro Empresa & Serviços \\
\hline Qtd. & $\%$ Vencido & Natureza Jurídica & Porte da Empresa & Segmento \\
\hline \multicolumn{7}{|c|}{} & & Micro Empresa & Serviços \\
\hline 17 & $1,72 \%$ & Sociedade Limitada & Micro Empresa & Serviços \\
\hline 18 & $1,69 \%$ & Sociedade Limitada & Sicro Empresa & Comércio \\
\hline 19 & $1,66 \%$ & Sociedade Limitada & Empresa de Pequeno Porte & Serviços \\
\hline 20 & $1,66 \%$ & Empresa Individual & Micro Empresa & Serviços \\
\hline 21 & $1,62 \%$ & Sociedade Limitada & Micro Empresa & Comércio \\
\hline 22 & $1,57 \%$ & Sociedade Limitada & Micro Empresa & Serviços \\
\hline 23 & $1,44 \%$ & Sociedade Limitada & Empresa de Pequeno Porte & Serviços \\
\hline 24 & $1,41 \%$ & Empresa Individual & Micro & \\
\hline
\end{tabular}

UFAMBR, Manaus, v. 2, n. 3, art. 3, pp. 35-57, julho-dezembro, 2020 http://www.periodicos.ufam.edu.br/ufambr 
Perfil dos Clientes Inadimplentes de uma Empresa de Factoring em uma Capital Brasileira Baseada na Teoria da Curva Abc

\begin{tabular}{|c|c|c|c|c|}
\hline 25 & $1,37 \%$ & Sociedade Limitada & Micro Empresa & Serviços \\
\hline 26 & $1,27 \%$ & Eireli & Micro Empresa & Serviços \\
\hline 27 & $1,23 \%$ & Empresa Individual & Micro Empresa & Comércio \\
\hline 28 & $1,19 \%$ & Sociedade Limitada & Micro Empresa & Comércio \\
\hline 29 & $1,16 \%$ & Sociedade Limitada & Micro Empresa & Serviços \\
\hline 30 & $1,11 \%$ & Sociedade Limitada & Micro Empresa & Serviços \\
\hline 31 & $1,08 \%$ & Empresa Individual & Micro Empresa & Serviços \\
\hline 32 & $1,06 \%$ & Sociedade Limitada & Micro Empresa & Comércio \\
\hline 33 & $0,87 \%$ & Sociedade Limitada & Micro Empresa & Serviços \\
\hline 34 & $0,80 \%$ & Sociedade Limitada & Micro Empresa & Serviços \\
\hline 35 & $0,80 \%$ & Sociedade Limitada & Micro Empresa & Comércio \\
\hline 36 & $0,79 \%$ & Empresa Individual & Micro Empresa & Serviços \\
\hline 37 & $0,77 \%$ & Empresa Individual & Micro Empresa & Serviços \\
\hline 38 & $0,71 \%$ & Empresa Individual & Micro Empresa & Serviços \\
\hline 39 & $0,70 \%$ & Eireli & Micro Empresa & Comércio \\
\hline 40 & $0,70 \%$ & Sociedade Limitada & Empresa de Pequeno Porte & Serviços \\
\hline 41 & $0,68 \%$ & Empresa Individual & Micro Empresa & Serviços \\
\hline 42 & $0,68 \%$ & Sociedade Limitada & Micro Empresa & Serviços \\
\hline 43 & $0,66 \%$ & Sociedade Limitada & Micro Empresa & Serviços \\
\hline 44 & $0,65 \%$ & Empresa Individual & Empresa de Pequeno Porte & Comércio \\
\hline 45 & $0,62 \%$ & Empresa Individual & Micro Empresa & Serviços \\
\hline 46 & $0,60 \%$ & Sociedade Limitada & Empresa de Pequeno Porte & Serviços \\
\hline 47 & $0,59 \%$ & Empresa Individual & Micro Empresa & Serviços \\
\hline 48 & $0,54 \%$ & Sociedade Limitada & Micro Empresa & Serviços \\
\hline 49 & $0,52 \%$ & Sociedade Limitada & Micro Empresa & Serviços \\
\hline 50 & $0,52 \%$ & Sociedade Limitada & Micro Empresa & Industria \\
\hline 51 & $0,52 \%$ & Empresa Individual & Micro Empresa & Serviços \\
\hline 52 & $0,52 \%$ & Sociedade Limitada & Empresa de Pequeno Porte & Comércio \\
\hline 53 & $0,44 \%$ & Sociedade Limitada & Micro Empresa & Serviços \\
\hline 54 & $0,41 \%$ & Sociedade Limitada & Micro Empresa & Industria \\
\hline 55 & $0,40 \%$ & Profissional Liberal & Não se aplica & Serviços \\
\hline 56 & $0,40 \%$ & Sociedade Limitada & Micro Empresa & Serviços \\
\hline 57 & $0,35 \%$ & Sociedade Limitada & Micro Empresa & Serviços \\
\hline 58 & $0,35 \%$ & Empresa Individual & Micro Empresa & Comércio \\
\hline 59 & $0,34 \%$ & Empresa Individual & Micro Empresa & Serviços \\
\hline Qtd. & $\%$ Vencido & Natureza Jurídica & Porte da Empresa & Segmento \\
\hline & & & & continua \\
\hline 60 & $0,33 \%$ & Sociedade Limitada & Micro Empresa & Serviços \\
\hline 61 & $0,32 \%$ & Sociedade Limitada & Micro Empresa & Serviços \\
\hline 62 & $0,31 \%$ & Empresa Individual & Micro Empresa & Serviços \\
\hline 63 & $0,31 \%$ & Sociedade Limitada & Micro Empresa & Serviços \\
\hline 64 & $0,30 \%$ & Empresa Individual & Micro Empresa & Serviços \\
\hline 65 & $0,30 \%$ & Empresa Individual & Micro Empresa & Comércio \\
\hline 66 & $0,30 \%$ & Empresa Individual & Micro Empresa & Serviços \\
\hline
\end{tabular}


Perfil dos Clientes Inadimplentes de uma Empresa de Factoring em uma Capital Brasileira Baseada na Teoria da Curva Abc

\begin{tabular}{|c|c|c|c|c|}
\hline 67 & $0,30 \%$ & Empresa Individual & Micro Empresa & Serviços \\
\hline 68 & $0,30 \%$ & Sociedade Limitada & Micro Empresa & Serviços \\
\hline 69 & $0,29 \%$ & Sociedade Limitada & Micro Empresa & Serviços \\
\hline 70 & $0,29 \%$ & Sociedade Limitada & Micro Empresa & Serviços \\
\hline 71 & $0,28 \%$ & Sociedade Limitada & Micro Empresa & Serviços \\
\hline 72 & $0,26 \%$ & Empresa Individual & Micro Empresa & Comércio \\
\hline 73 & $0,24 \%$ & Empresa Individual & Micro Empresa & Comércio \\
\hline 74 & $0,24 \%$ & Eireli & Empresa de Pequeno Porte & Serviços \\
\hline 75 & $0,24 \%$ & Sociedade Limitada & Empresa de Pequeno Porte & Serviços \\
\hline 76 & $0,24 \%$ & Empresa Individual & Micro Empresa & Serviços \\
\hline 77 & $0,22 \%$ & Empresa Individual & Micro Empresa & Serviços \\
\hline 78 & $0,22 \%$ & Sociedade Limitada & Micro Empresa & Comércio \\
\hline 79 & $0,22 \%$ & Eireli & Micro Empresa & Comércio \\
\hline 80 & $0,21 \%$ & Empresa Individual & Micro Empresa & Serviços \\
\hline 81 & $0,20 \%$ & Sociedade Limitada & Micro Empresa & Serviços \\
\hline 82 & $0,20 \%$ & Sociedade Limitada & Micro Empresa & Comércio \\
\hline 83 & $0,19 \%$ & Empresa Individual & Micro Empresa & Comércio \\
\hline 84 & $0,18 \%$ & Empresa Individual & Micro Empresa & Serviços \\
\hline 85 & $0,18 \%$ & Empresa Individual & Micro Empresa & Serviços \\
\hline 86 & $0,18 \%$ & Empresa Individual & Micro Empresa & Comércio \\
\hline 87 & $0,17 \%$ & Empresa Individual & Micro Empresa & Serviços \\
\hline 88 & $0,17 \%$ & Empresa Individual & Micro Empresa & Serviços \\
\hline 89 & $0,17 \%$ & Empresa Individual & Micro Empresa & Comércio \\
\hline 90 & $0,17 \%$ & Empresa Individual & Micro Empresa & Serviços \\
\hline 91 & $0,17 \%$ & Empresa Individual & Micro Empresa & Comércio \\
\hline 92 & $0,17 \%$ & Sociedade Limitada & Micro Empresa & Serviços \\
\hline 93 & $0,16 \%$ & Sociedade Limitada & Empresa de Pequeno Porte & Serviços \\
\hline 94 & $0,16 \%$ & Sociedade Limitada & Micro Empresa & Serviços \\
\hline 95 & $0,15 \%$ & Sociedade Limitada & Micro Empresa & Comércio \\
\hline 96 & $0,15 \%$ & Profissional Liberal & Não se aplica & Serviços \\
\hline 97 & $0,14 \%$ & Sociedade Limitada & Micro Empresa & Serviços \\
\hline 98 & $0,14 \%$ & Sociedade Limitada & Micro Empresa & Serviços \\
\hline 99 & $0,14 \%$ & Sociedade Limitada & Empresa de Pequeno Porte & Serviços \\
\hline 100 & $0,14 \%$ & Profissional Liberal & Não se aplica & Serviços \\
\hline 101 & $0,14 \%$ & Empresa Individual & Micro Empresa & Comércio \\
\hline 102 & $0,14 \%$ & Empresa Individual & Micro Empresa & Serviços \\
\hline Qtd. & $\%$ Vencido & Natureza Jurídica & Porte da Empresa & Segmento \\
\hline & & & & continua \\
\hline 103 & $0,14 \%$ & Empresa Individual & Micro Empresa & Serviços \\
\hline 104 & $0,13 \%$ & Sociedade Limitada & Micro Empresa & Comércio \\
\hline 105 & $0,13 \%$ & Empresa Individual & Micro Empresa & Comércio \\
\hline 106 & $0,12 \%$ & Sociedade Limitada & Micro Empresa & Comércio \\
\hline 107 & $0,12 \%$ & Sociedade Limitada & Micro Empresa & Comércio \\
\hline 108 & $0,12 \%$ & Sociedade Limitada & Empresa de Pequeno Porte & Serviços \\
\hline
\end{tabular}


Perfil dos Clientes Inadimplentes de uma Empresa de Factoring em uma Capital Brasileira Baseada na Teoria da Curva Abc

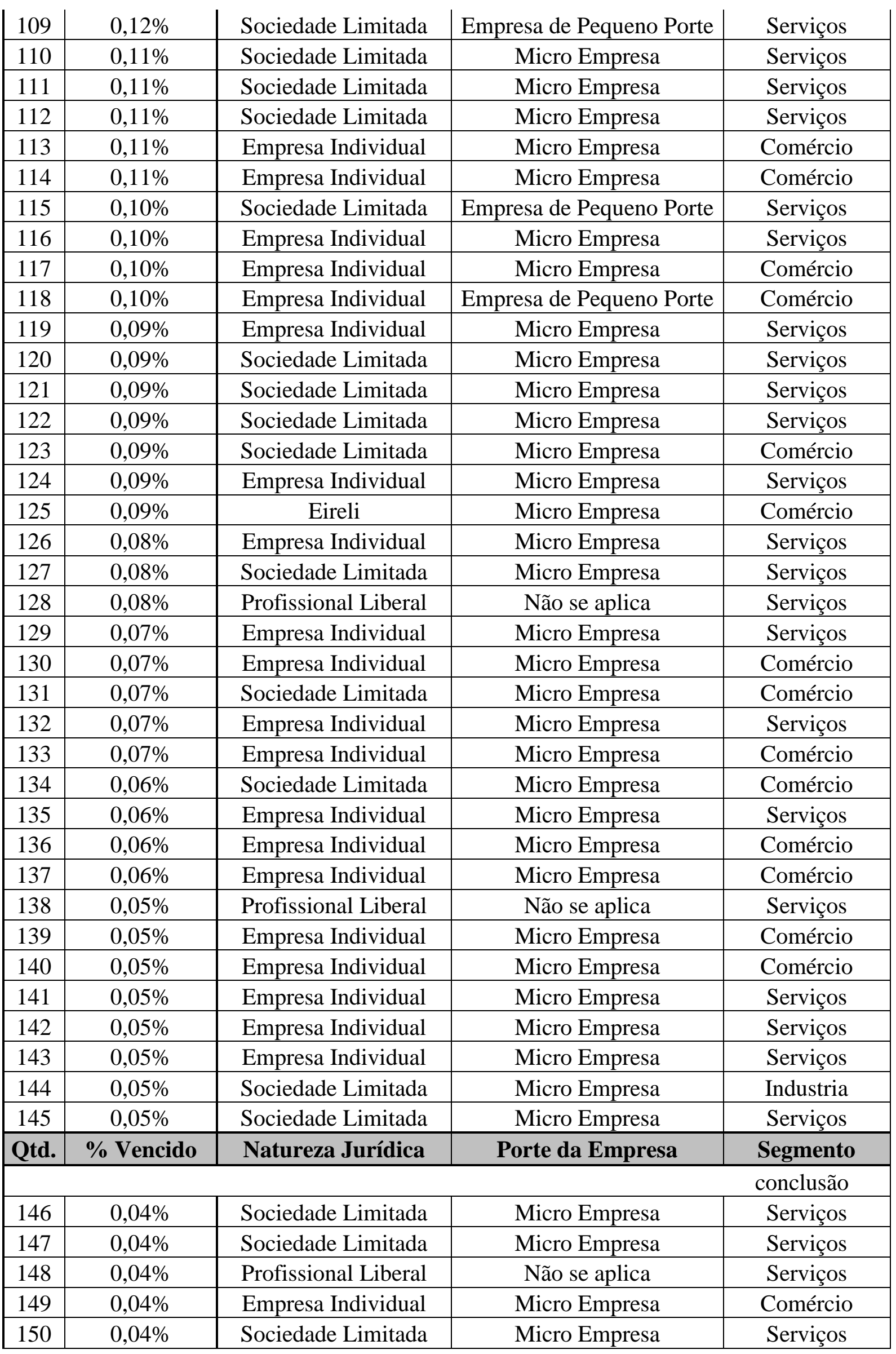


Perfil dos Clientes Inadimplentes de uma Empresa de Factoring em uma Capital Brasileira Baseada na Teoria da Curva Abc

\begin{tabular}{|c|c|c|c|c|}
151 & $0,04 \%$ & Sociedade Limitada & Micro Empresa & Serviços \\
\hline 152 & $0,04 \%$ & Empresa Individual & Micro Empresa & Comércio \\
\hline 153 & $0,04 \%$ & Empresa Individual & Micro Empresa & Comércio \\
\hline 154 & $0,04 \%$ & Profissional Liberal & Não se aplica & Serviços \\
\hline 155 & $0,03 \%$ & Empresa Individual & Micro Empresa & Comércio \\
\hline 156 & $0,03 \%$ & Empresa Individual & Micro Empresa & Serviços \\
\hline 157 & $0,03 \%$ & Eireli & Micro Empresa & Serviços \\
\hline 158 & $0,03 \%$ & Empresa Individual & Micro Empresa & Serviços \\
\hline 159 & $0,03 \%$ & Empresa Individual & Micro Empresa & Serviços \\
\hline 160 & $0,03 \%$ & Sociedade Limitada & Micro Empresa & Serviços \\
\hline 161 & $0,03 \%$ & Sociedade Limitada & Micro Empresa & Comércio \\
\hline 162 & $0,03 \%$ & Sociedade Limitada & Micro Empresa & Serviços \\
\hline 163 & $0,03 \%$ & Sociedade Limitada & Micro Empresa & Serviços \\
\hline 164 & $0,03 \%$ & Empresa Individual & Micro Empresa & Comércio \\
\hline 165 & $0,03 \%$ & Empresa Individual & Micro Empresa & Comércio \\
\hline 166 & $0,03 \%$ & Profissional Liberal & Não se aplica & Serviços \\
\hline 167 & $0,03 \%$ & Sociedade Limitada & Micro Empresa & Serviços \\
\hline 168 & $0,02 \%$ & Sociedade Limitada & Micro Empresa & Serviços \\
\hline 169 & $0,02 \%$ & Empresa Individual & Micro Empresa & Serviços \\
\hline 170 & $0,02 \%$ & Sociedade Limitada & Micro Empresa & Comércio \\
\hline 171 & $0,01 \%$ & Sociedade Limitada & Empresa de Pequeno Porte & Serviços \\
\hline 172 & $0,01 \%$ & Sociedade Limitada & Micro Empresa & Comércio \\
\hline 173 & $0,01 \%$ & & Eicro Empresa & Serviços \\
\hline 174 & $0,00 \%$ & Empresa Individual & Micro Empresa & Serviços \\
\hline 175 & $-0,03 \%$ & Empresa Individual & Micro Empresa & Comércio \\
\hline 176 & $-0,06 \%$ & Sociedade Limitada & Micro Empresa & Comércio \\
\hline
\end{tabular}

Fonte: elaborada pelos autores

\subsection{Curva ABC: Análise dos Clientes Classe A}

Conforme metodologia apresentada, a ferramenta utilizada para identificação dos clientes classe A foi a teoria de Pareto denominada de Curva ABC. Aplicando essa ferramenta nos dados cedidos pela empresa de Factoring estudada foi possível identificar quais clientes detém a maior representatividade de inadimplência quanto ao valor geral acumulado.

Gráfico 1. Gráfico $\mathrm{ABC}$

$$
19,90 \%
$$

$73,49 \%$

36

52

88

Fonte: elaborado pelos autores 
Perfil dos Clientes Inadimplentes de uma Empresa de Factoring em uma Capital Brasileira Baseada na Teoria da Curva Abc

Constata-se após análise do Gráfico ABC que 73,49\% do valor devido geral da empresa estão concentrados em 36 clientes (20\%). Após a identificação dos devedores Classe A foi possível analisar esses clientes quanto às possíveis causas que levaram a empresa ao quadro de endividamento.

\subsection{Perfil dos Clientes Inadimplentes Classe A}

Foram analisados os clientes inadimplentes classe A quanto ao porte da empresa, natureza jurídica, segmento e ramo de atividade com o intuito de traçar um perfil dos clientes inadimplentes. Abaixo os resultados obtidos:

Gráfico 2. Perfil dos Clientes Classe A: Porte da Empresa x Natureza Jurídica

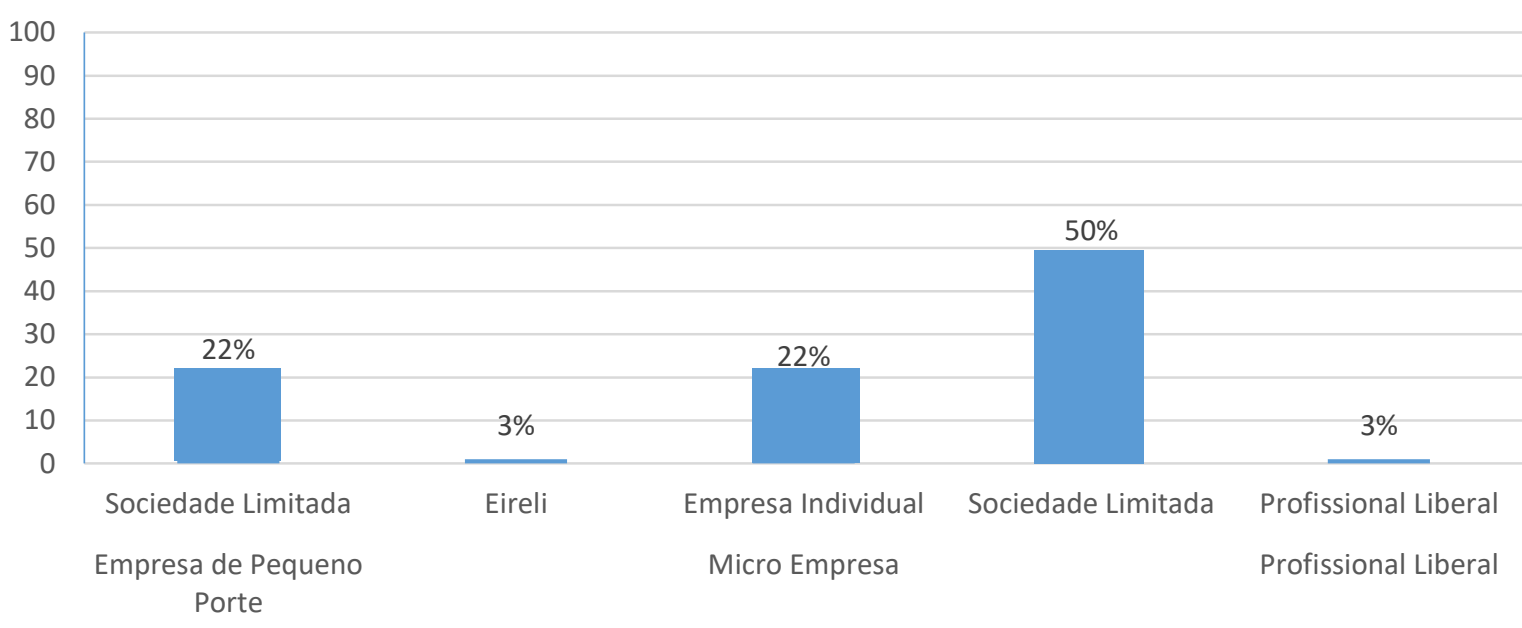

Fonte: elaborado pelos autores

Constata-se pela análise do gráfico 2 que $22 \%$ dos clientes inadimplentes classificados como Classe A são empresas de Pequeno Porte e com natureza Jurídica de Sociedade Limitada.

Quanto às microempresas, conforme analisado no gráfico, possuem maior representatividade nos clientes de Classe A com $75 \%$ de representatividade, sendo divididos em naturezas jurídicas como: Eireli - 3\%, Empresa Individual - 22\% e Sociedade Limitada - 50\%. Já as empresas classificadas como profissionais liberais representam $3 \%$ dos clientes classe A.

É importante destacar que o Gráfico 2 demonstrou que as empresas de Sociedade Limitada representam $72 \%$ dos clientes classificados como Classe A, sendo separados apenas quanto ao seu porte, 50\% - Micro Empresas e 22\% - Empresa de Pequeno Porte.

Gráfico 3. Perfil dos clientes Classe A: Segmentação 
Perfil dos Clientes Inadimplentes de uma Empresa de Factoring em uma Capital Brasileira Baseada na Teoria da Curva Abc

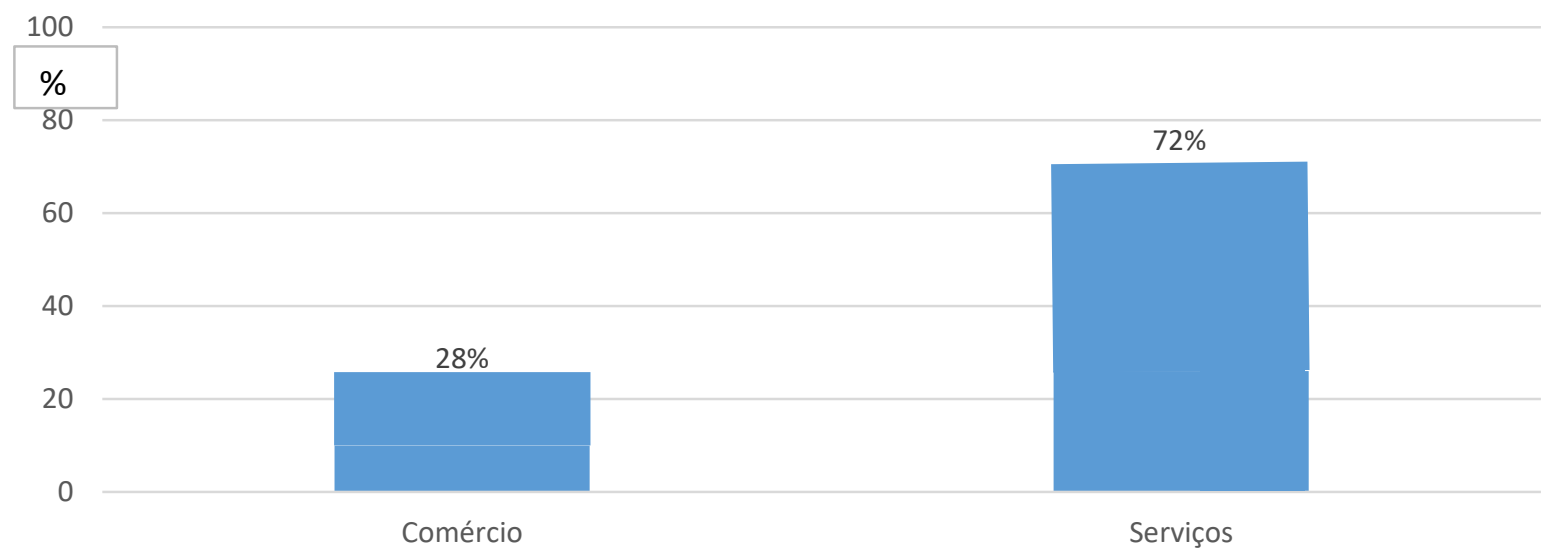

Fonte: elaborado pelos autores

Por meio do gráfico 3 é possível confirmar que $28 \%$ dos clientes inadimplentes classificados como Classe A são do Segmento Comercial, enquanto $72 \%$ das empresas são do Segmento de Serviços.

Gráfico 4. Perfil dos Clientes Classe A: Ramo de Atividade

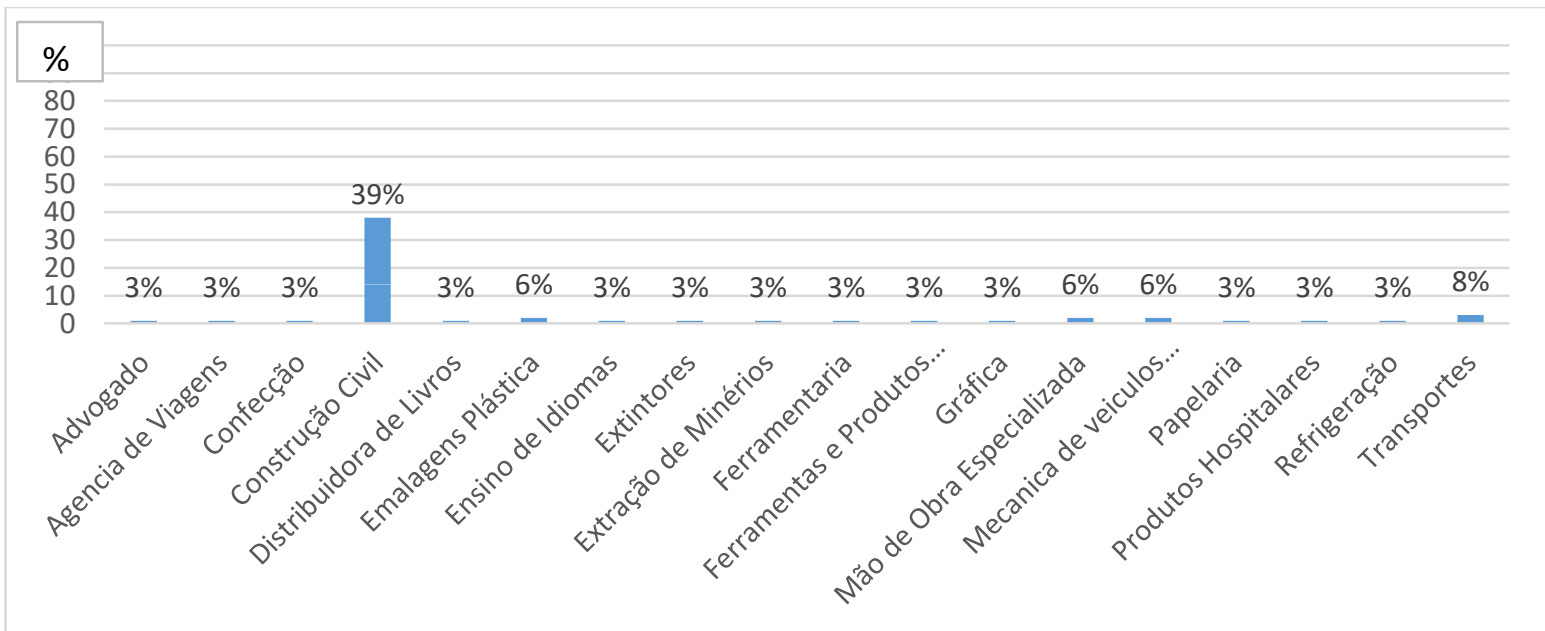

Fonte: elaborado pelos autores

O Gráfico 4 constata que o ramo de atividade mais representativo dos clientes inadimplentes classificados como Classe A são do Ramo da Construção (Serviços) - 39\%, seguidos pelo ramo de transportes (Serviços) - 8\%, Mecânica de Veículos Automotores (Serviços) - 6\%, Mão de Obra Especializada (Serviços) - 6\% e Embalagens Plástica (Comércio) - 6\%.

\subsection{Possíveis fatores da inadimplência}

Segundo a Factoring estudada os possíveis fatores que podem acarretar a inadimplência são: Fator de Compras, Tempo de Fundação e Tempo de Cadastro.

Fator de Compra: No jargão do Factoring a expressão fator de compra - representa o referencial de preço da compra dos créditos. A composição do fator (referência de preço pelo qual são adquiridos os direitos creditórios originados de vendas mercantis), leva em conta os seguintes itens: custo - oportunidade do capital próprio, custos fixos, custos variáveis, impostos operacionais, despesas de cobrança e expectativa de risco / lucro. 
Perfil dos Clientes Inadimplentes de uma Empresa de Factoring em uma Capital Brasileira Baseada na Teoria da Curva Abc

A Empresa estudada aplica 3 tipos de fatores para cada um dos seus serviços. Para compra de cheques pré-datados a empresa estudada aplica fator de $7.98 \%$ a.m, para compra de duplicatas o fator passa a ser de $6.98 \%$ a.m, enquanto o serviço de adiantamento para compra de matéria prima é aplicado o maior fator de compras $-9.98 \%$ a.m.

Esses percentuais podem ser alterados conforme histórico de liquidez e tempo de cadastro, podendo chegar até a $4.98 \%$ a.m para negociação com duplicatas, $6.98 \%$ a.m para negociação com cheques e $7.98 \%$ a.m para o serviço de adiantamento para compra de matéria prima. A empresa de Factoring estudada acredita que quanto maior o fator aplicado nas negociações de títulos com os seus clientes maior é o risco do negócio e por conseguinte o elevado grau de inadimplência.

- $\quad$ Tempo de Fundação: A empresa de Factoring estudada acredita que quanto menor a experiência dos clientes no mercado em que atua maior pode ser o grau de inadimplência trazido por esses clientes.

Tempo de Cadastro: Acredita-se que quanto maior o tempo de relação dos clientes possuem com a empresa de Factoring menor o risco apresentado por esses clientes e por consequência menor o grau de inadimplência.

Gráfico 5. Perfil dos Clientes Classe A: Fator de Compra x \% Inadimplência

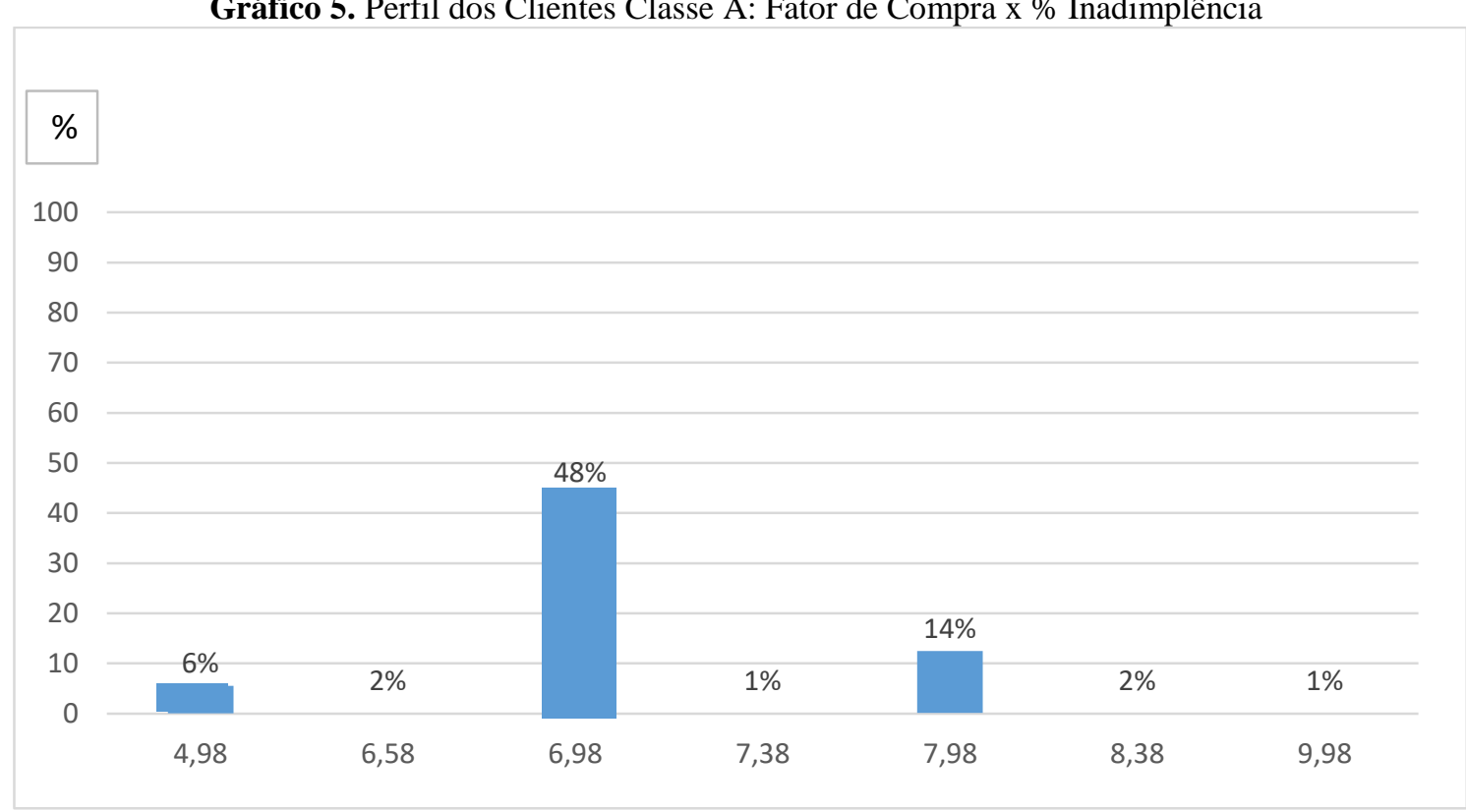

Fonte: elaborado pelos autores.

Analisando o Gráfico 5 é possível constatar que $48 \%$ do valor geral da inadimplência está composto por clientes com fator de compra de $6.98 \%$ a.m, enquanto $14 \%$ do valor geral devido, está composta por clientes que operam com fator de compra a $7.98 \%$ a.m, o que desfaz a crença da empresa que quanto maior o fator de compra aplicado maior o índice da inadimplência.

Gráfico 6. Perfil dos clientes Classe A: Tempo de Fundação x Inadimplência 
Perfil dos Clientes Inadimplentes de uma Empresa de Factoring em uma Capital Brasileira Baseada na Teoria da Curva Abc

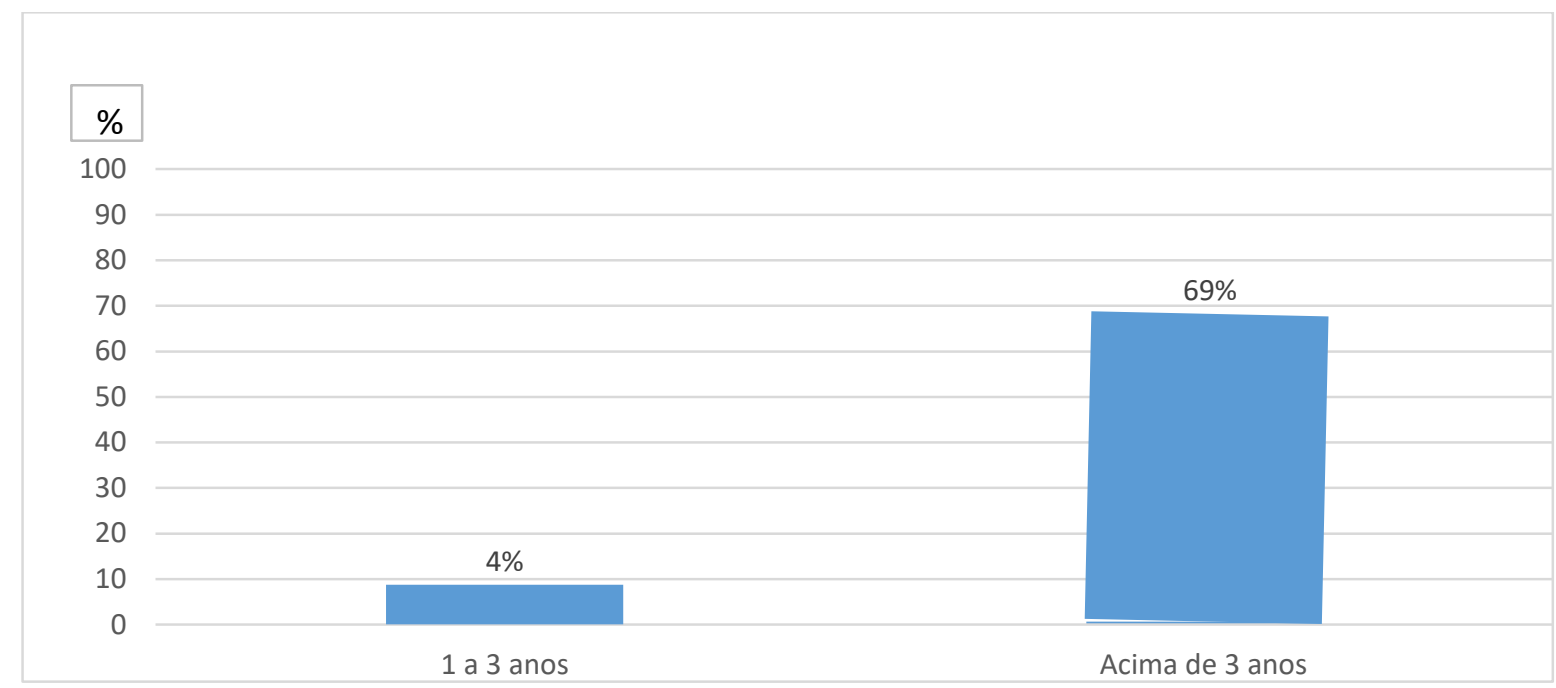

Fonte: elaborada pelos autores

A empresa de Factoring possui $69 \%$ do valor geral da inadimplência concentrado em clientes que possuem acima de 3 anos de tempo de fundação. O que minimiza a tese de que quanto menor o tempo de fundação da empresa maior o grau da inadimplência. O que o Gráfico 6 demonstra é justamente o inverso, quanto maior o tempo de fundação, maior é o valor da inadimplência.

Gráfico 7. Perfil dos Clientes Classe A: Tempo de Cadastro x \% Inadimplência

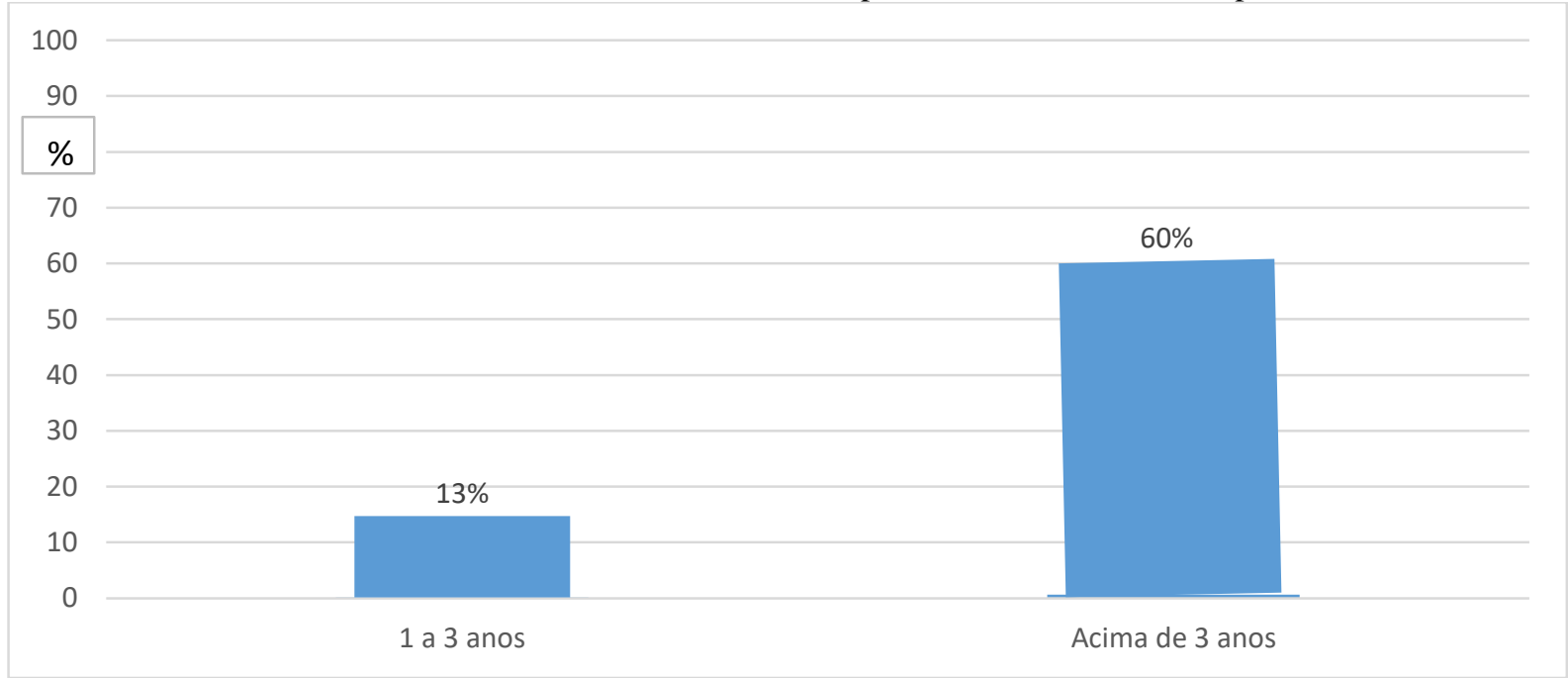

Fonte: Elaborada pelos Autores

Após análise do Gráfico 7 constatou-se que $60 \%$ do valor geral de inadimplência está composto por clientes que possuem mais de 3 anos de tempo de cadastro, enquanto $13 \%$ do valor geral de inadimplência são formados por clientes com tempo de cadastro entre 1 e 3 anos. Logo, a perspectiva que a empresa tinha em relação ao tempo de cadastro dos clientes em função da inadimplência também não se concretizou, uma vez que o gráfico apresentou justamente o inverso. Quanto maior o tempo de cadastro entre a empresa de Factoring e os seus clientes, maior o valor da inadimplência.

\section{CONSIDERAÇÕES FINAIS}


Perfil dos Clientes Inadimplentes de uma Empresa de Factoring em uma Capital Brasileira Baseada na Teoria da Curva Abc

O presente artigo teve como propósito identificar as principais características dos perfis dos clientes de uma empresa de Factoring localizada em Manaus-AM, além de confirmar se os fatores Compra, Tempo de Fundação e Tempo de Cadastro são condicionantes para o endividamento dos seus clientes. Como pode ser observado nestes resultados, a gestão adequada do caixa é crucial para sobrevivência e sustentabilidade econômica, tanto das grandes quanto das pequenas organizações.

O objetivo geral foi atingido, uma vez que foi encontrada uma relação entre o perfil dos clientes inadimplentes, com os serviços de crédito oferecido pela empresa. Por meio dos resultados obtidos, e com a literatura estudada, constatou-se que mesmo com todas as ferramentas que a Factoring disponibiliza para concessão de crédito, sugere-se que algumas variáveis, mais incisivas, também sejam analisadas. Os C's do crédito que é uma ferramenta que avalia o risco do cliente, é uma ferramenta administrativa relevante para conceder crédito e precisa ser levado em consideração pela empresa estudada uma vez que os principais questionamentos para a inadimplência não se concretizaram após análise dos dados.

O que se constatou foi uma menor "rigidez" na análise do crédito em função do tempo de cadastro que os clientes possuem junto a empresa de Factoring. Faz-se necessário manter a rigidez quanto a análise desses créditos para diminuir o grau de endividamento dos seus clientes.

Verificou-se ainda, nessa empresa em questão, que empresas de Sociedade Limitada, no segmento de serviços são mais tendenciosas a não honrar com o pagamento, e consequentemente se tornar inadimplente com a Factoring estudada.

Elaboraram-se os objetivos específicos a fim de chegar ao objetivo geral. Para isso em um primeiro momento, foi analisado o conceito de crédito, risco e inadimplência no referencial teórico, destacando aplicações que ocorrem na prática na empresa em estudo. O segundo e terceiro objetivo, foi alcançado a partir de um banco de dados fornecidos pela empresa estudada em questão com a finalidade de levantar o perfil dos clientes inadimplentes dessa empresa e levantar também a característica dos clientes inadimplentes, quanto aos questionamentos apontados pela empresa em questão como fator do inadimplemento. Por fim, analisaram-se e correlacionaram-se os dados levantados no presente artigo.

Destaca-se que não se pode generalizar com este estudo, uma vez que variáveis foram testadas em uma empresa de Factoring específica. Porém, com as ferramentas disponibilizadas para análise de crédito, ainda ocorrem problemas com inadimplência. No momento de concessão de crédito para o cliente, algumas variáveis podem ser questionadas antes da contratação para redução de riscos para a organização.

Como limitação para realizar este trabalho, observou-se a dificuldade em referências específicas sobre esse assunto. $\mathrm{O}$ fato de analisar uma única empresa de Factoring também foi um fator limitador. Assim, para trabalhos futuros, sugere-se aplicar e relacionar os perfis de clientes inadimplentes com os créditos, em outras Factoring's e em outras instituições financeiras.

\section{REFERÊNCIAS}

Associação Nacional de Fomento Comercial (ANFAC). (2017). Disponível em: <http://www.anfac.com.br/v3/>Acesso em 7 fevereiro de 2017. 
Perfil dos Clientes Inadimplentes de uma Empresa de Factoring em uma Capital Brasileira Baseada na Teoria da Curva Abc

Alves, L. C. O., Silva, M. C., \& Siqueira, J. R. M. (2008). Factoring: Uma Opção das Micros e Pequenas Empresas aos Custos Financeiros, de Inadimplência e Gerenciais? Revista de Negócios, Blumenau, v. 13, n.4, p. 11-26.

Blatt, A. (1999). Créditos inadimplidos e inadimplência. $2^{\mathrm{a}}$ ed São Paulo: Ed. STS.

Capelletto, L. R. \& Corrar, L. J. (2008). Índices de risco sistêmico para o setor bancário. Revista Contabilidade e Finanças. (pp. 8-9). 19 (47), 6-18.

Carvalho, J.M.C. (2002). Logística. $3^{a}$ ed. Lisboa: Edições Silabo. p. 220-230.

Donini, A. C. (2004). Manual do Factoring. São Paulo: Editora Klarear.

Fortuna, E. (2001). Mercado Financeiro: produtos e serviços. 14 ${ }^{\mathrm{a}}$ ed. Rio de Janeiro: Editora Qualitymark.

Gonçalves, E. B., Gouvêa, M. A., \& Mantovani, D. M. N. (2013). Análise de risco de crédito com o uso de regressão logística. Revista Contemporânea de Contabilidade. 10 (20), 139160.

Gil, A. C. (2002). Como elaborar projetos de pesquisa. 4 ed. São Paulo: Atlas.

Goodman, J.E. (1993). Dicionário de termos financeiros e de investimento. São Paulo: Nobel. p. $400-426$.

Leite, L. L. (2011). Factoring no Brasil. 12a ed., pp. 221-225, São Paulo: Atlas.

Pinto, C.V. (2002). Organização e gestão da manutenção. Lisboa: Monitor. p. 21-42

Robbins, S. P. (2009). Fundamentos do Comportamento Organizacional. São Paulo: Prentice Hall.

Serviço de Apoio às Micro e Pequenas Empresas de São Paulo (SEBRAE SP). (2014). Causa Mortis: o sucesso e o fracasso das empresas nos primeiros cinco anos de vida.

Schrickel, W. K. (1995). Análise de crédito: concessão e gerência de empréstimo. $4^{\mathrm{a}}$ ed. São Paulo: Atlas.

Santos, J. O. (2000). Análise de crédito para empresas e pessoas físicas. São Paulo: Atlas.

Sandroni, P. (1999). Novíssimo dicionário de economia. São Paulo: Best Seller.

Sacomano, J.B. (2004). Administração de produção na construção civil: o gerenciamento de obras baseado em critérios competitivos. São Paulo: Arte \& Ciência. p. 93-98.

Vergara, S. C. (2003). Projetos e Relatórios de Pesquisa em Administração. 4. ed. São Paulo: Atlas.

Wolf, F. M. (2008). As práticas de análise para concessão de crédito numa empresa de fomento mercantil (Factoring). Graduação em Ciências Contábeis, Universidade Federal de Santa

Catarina, Florianópolis, SC, Brasil.

Yin, R. K. (2001). Estudo de caso: Planejamento e métodos. 2.ed. Porto Alegre: Bookman. 